\title{
Astrocyte Regulation of Blood Flow in the Brain
}

\author{
Brian A. MacVicar ${ }^{1}$ and Eric A. Newman ${ }^{2}$ \\ ${ }^{1}$ Djavad Mowafaghian Centre for Brain Health, Department of Psychiatry, University of British Columbia, \\ Vancouver, British Columbia V6T 2B5, Canada \\ ${ }^{2}$ Department of Neuroscience, University of Minnesota, Minneapolis, Minnesota 55455 \\ Correspondence: ean@umn.edu
}

Neuronal activity results in increased blood flow in the brain, a response named functional hyperemia. Astrocytes play an important role in mediating this response. Neurotransmitters released from active neurons evoke $\mathrm{Ca}^{2+}$ increases in astrocytes, leading to the release of vasoactive metabolites of arachidonic acid from astrocyte endfeet onto blood vessels. Synthesis of prostaglandin E2 (PGE2) and epoxyeicosatrienoic acids (EETs) dilate blood vessels, whereas 20-hydroxyeicosatetraenoic acid (20-HETE) constricts vessels. The release of $\mathrm{K}^{+}$from astrocyte endfeet may also contribute to vasodilation. Oxygen modulates astrocyte regulation of blood flow. Under normoxic conditions, astrocytic $\mathrm{Ca}^{2+}$ signaling results in vasodilation, whereas under hyperoxic conditions, vasoconstriction is favored. Astrocytes also contribute to the generation of vascular tone. Tonic release of both 20HETE and ATP from astrocytes constricts vascular smooth muscle cells, generating vessel tone. Under pathological conditions, including Alzheimer's disease and diabetic retinopathy, disruption of normal astrocyte physiology can compromise the regulation of blood flow.

\begin{abstract}
strocytes have an intimate relationship with Ablood vessels in the brain as their endfoot processes completely envelop all cerebral blood vessels. The interplay between astrocyte endfeet and the cerebral vasculature is an area of intense investigation as work over the past 10 years has shown that astrocytes are involved in the regulation of cerebral blood flow (CBF). Matching CBF to the metabolic demands of brain activity is essential for healthy brain function. The maintenance of brain homeostasis and cognitive processing requires substantial energy expenditures relative to the rest of the human body. It is estimated that $20 \%$ of total body
\end{abstract}

energy consumption is caused by brain activity, although the brain represents only $2 \%$ of the total body weight. Calculations of the brain energy budget have estimated that the greatest proportion of the energy expenditure in the brain is attributed to synaptic transmission (Howarth et al. 2012). This suggests that synaptic transmission will be preferentially impacted by reductions in the energy supply to the brain. Oxidative metabolism in the brain is almost exclusively owing to aerobic glycolysis, indicating that glucose and oxygen are the primary energy fuels in the brain (Magistretti et al. 2000). Therefore, the roles of astrocytes in reg-

Editors: Ben A. Barres, Marc R. Freeman, and Beth Stevens

Additional Perspectives on Glia available at www.cshperspectives.org

Copyright (C) 2015 Cold Spring Harbor Laboratory Press; all rights reserved; doi: 10.1101/cshperspect.a020388

Cite this article as Cold Spring Harb Perspect Biol 2015;7:a020388 
ulating CBF is likely to be of fundamental importance in providing appropriate and consistent energy supply to support brain function.

There are two important levels at which CBF is regulated. Basal CBF, which is remarkably higher than the rest of the body (Magistretti et al. 2000), is regulated so that the brain receives an adequate supply of blood at all times. Autoregulatory mechanisms ensure that $\mathrm{CBF}$ does not vary in the face of changes in systemic blood pressure. $\mathrm{CBF}$ is also regulated in response to brain activity. It has long been recognized, since the classic papers of Mosso (1880) and Roy and Sherrington (1890), that the brain has an intrinsic ability to rapidly regulate its own blood supply in response to local energy requirements, a response named functional hyperemia. This homeostatic response is important for providing increased delivery of glucose and oxygen at times of intense activity and metabolic demand.

\section{HISTORICAL OVERVIEW OF FUNCTIONAL HYPEREMIA}

Functional hyperemia was first described in the 1880s by Angelo Mosso (1880), who observed changes in brain volume in patients with skull defects, allowing direct observation of the cortical surface. Mosso found that sensory stimuli produced an increase in brain volume, representing increased cortical blood flow. A decade later, Roy and Sherrington (1890) showed that stimulation of sensory nerves in dogs produced increases in cortical blood flow. They speculated that "the chemical products of cerebral metabolism can cause variations of the caliber of the cerebral vessels: that in this reaction the brain possesses an intrinsic mechanism by which its vascular supply can be varied locally in correspondence with local variations of functional activity."

In the late 1800s, around the same time that functional hyperemia was first observed, astrocyte morphology was described by Virchow (1858), Golgi (1894), Ramón y Cajal (1995) (first published in 1897), and others. They observed that astrocytes contacted both blood vessels, which are enveloped by astrocyte endfeet, and neurons (Fig. 1). Thus, astrocytes are ide- ally positioned to mediate neurovascular coupling, relaying signals from neurons to blood vessels. The association of astrocytes with blood vessels led Ramón y Cajal to suggest that these cells might regulate blood flow in the brain. Ramón y Cajal wrote, "The perivascular neuroglial cells live only in the proximity of the capillaries of the gray matter, to which they send one or more thick appendages inserted in the outer side of the endothelium. Each capillary gives insertion to thousands of these pseudopods (endfeet), which diverge in all directions. The object of such elements is to evoke, by contraction of the aforementioned appendices, local dilations of the vessels" (Ramón y Cajal 1895). Ramón y Cajal's suggestion that astrocytes regulate blood flow, albeit by an incorrect mechanism, was prescient.

More recently, astrocyte regulation of blood flow has been investigated directly. Paulson and Newman (1987) proposed that astrocytes mediate functional hyperemia by a $\mathrm{K}^{+}$siphoning mechanism, releasing $\mathrm{K}^{+}$onto blood vessels from their endfeet in response to neuronal activity. Later, Zonta et al. (2003) suggested that neurovascular coupling is mediated by the release of prostaglandins from astrocytes. They showed that prostaglandin E2 (PGE2) release, resulting from increases in glial $\mathrm{Ca}^{2+}$, evokes vessel dilation.

Since the publication of Zonta et al. (2003), the role of astrocytes in mediating functional hyperemia has been studied intensely. Several mechanisms of glial control of CBF have been proposed and tested. These mechanisms are discussed in the following sections.

\section{NEUROVASCULAR COUPLING}

It was originally hypothesized that the control of CBF flow was mediated by a negative feedback mechanism, whereby the generation of metabolites from active neurons (such as $\mathrm{CO}_{2}$ ) were the signals that resulted in increased $\mathrm{CBF}$ (Roy and Sherrington 1890). However, it is now recognized that brain activity itself can increase CBF. Indeed, CBF increases to such an extent that more oxygen is provided to active brain regions than is consumed. Recordings of tissue 


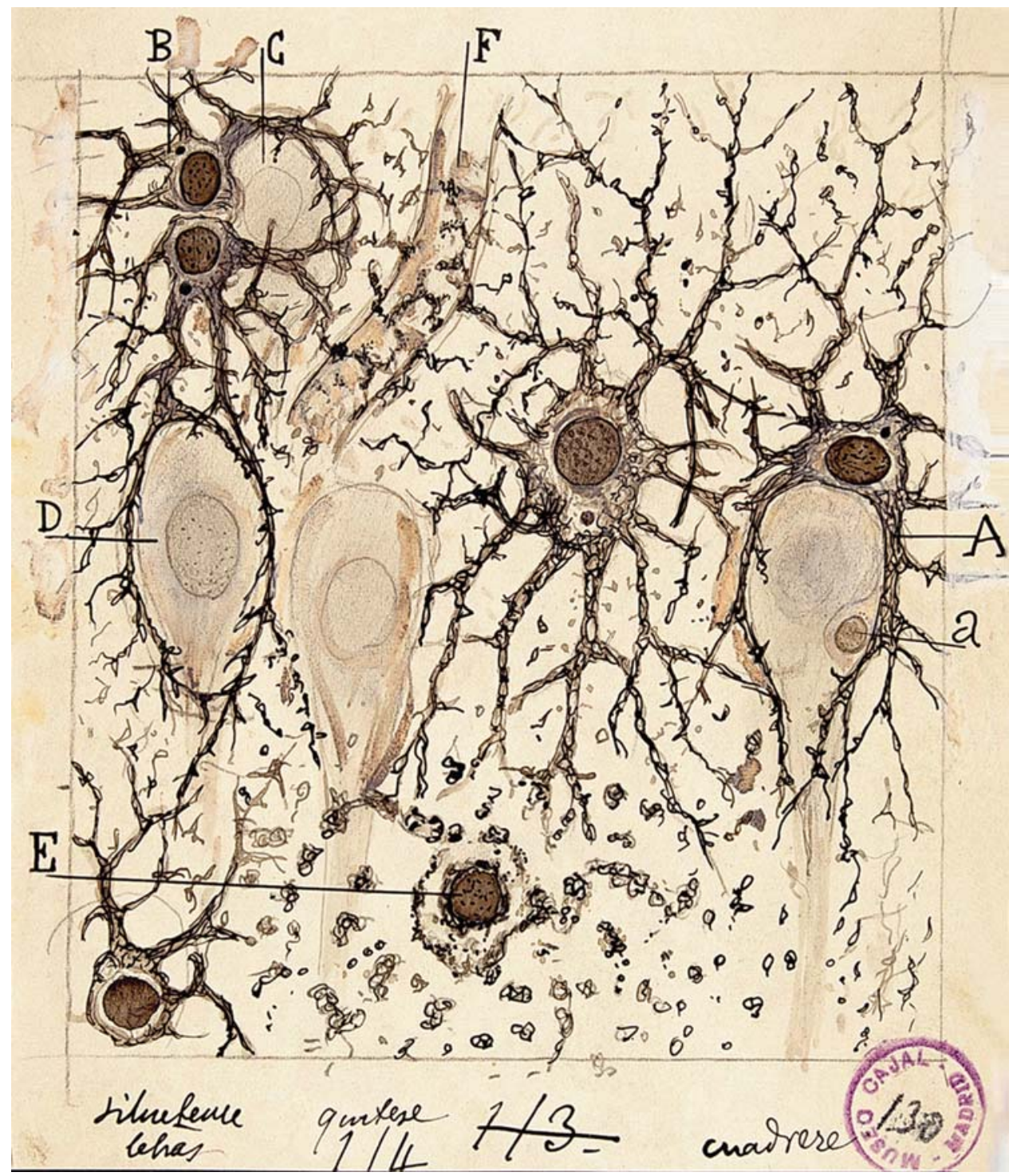

Figure 1. Drawing of brain astrocytes by Santiago Ramón y Cajal. $(A, B)$ Astrocytes, the darker cells in the drawing, contact both neurons, $(C, D)$ the lighter cells, and $(F)$ a blood vessel. As suggested by Ramón y Cajal, astrocytes are ideally situated to mediate signaling from neurons to blood vessels and to increase cerebral blood flow $(\mathrm{CBF})$ in response to neuronal activity.

$\mathrm{pO}_{2}$ levels during activation of cortical synaptic activity show that $\mathrm{pO}_{2}$ increases rapidly above basal levels during and after repetitive synaptic activity (Offenhauser et al. 2005; Devor et al. 2011). This oversupply of oxygen is the basis of the BOLD (blood oxygen level-dependent) effect in fMRI (functional magnetic resonance imaging), whereby increased levels of blood oxy- gen are detected by the change in the magnetic properties of hemoglobin as the proportion of oxygenated hemoglobin increases and the deoxygenated form is decreased. It is now recognized that synaptic and brain activity itself leads to enhanced CBF and that astrocytes are key players in mediating neurovascular coupling, the transduction of brain activity to alterations 


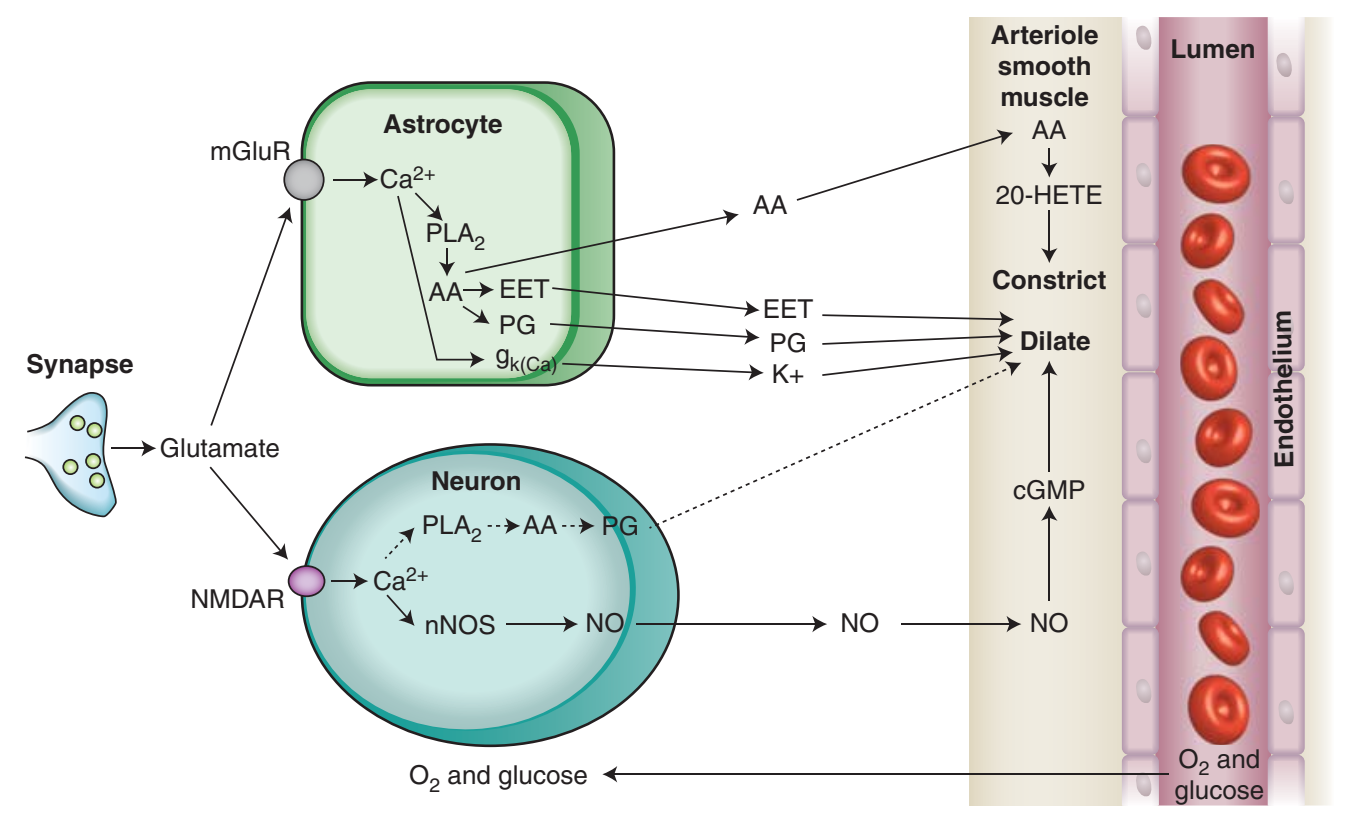

Figure 2. Summary of signaling pathways that mediate neurovascular coupling in the brain. Synaptically released glutamate acts on $N$-methyl-D-aspartate receptors (NMDARs) in neurons to increase $\left[\mathrm{Ca}^{2+}\right]_{\mathrm{i}}$, causing neuronal nitric oxide synthase (nNOS) to release nitric oxide (NO), which activates smooth muscle guanylate cyclase. Raised $\left[\mathrm{Ca}^{2+}\right]_{\mathrm{i}}$ may also (dashed line) generate arachidonic acid (AA) from phospholipase $\mathrm{A}_{2}\left(\mathrm{PLA}_{2}\right)$, which is converted to prostaglandins (PG) that dilate vessels. Glutamate also raises $\left[\mathrm{Ca}^{2+}\right]_{\mathrm{i}}$ in astrocytes by activating metabotropic glutamate receptors (mGluR), generating arachidonic acid, and three types of AA metabolites: prostaglandins and EETs in astrocytes, which dilate vessels, and 20-HETE in smooth muscle, which constricts vessels. An increase of $\left[\mathrm{Ca}^{2+}\right]_{\mathrm{i}}$ in astrocyte endfeet may also activate $\mathrm{Ca}^{2+}$-gated $\mathrm{K}^{+}$channels $\left(\mathrm{g}_{\mathrm{k}(\mathrm{Ca})}\right.$, alternative abbreviation, BK), releasing $\mathrm{K}^{+}$, which dilates vessels. (From Attwell et al. 2010; reprinted, with permission, from the authors.)

in CBF. Although direct signaling from neurons to blood vessels contributes to the regulation of CBF (Attwell et al. 2010), astrocytes play an important role in mediating neurovascular coupling (Fig. 2).

\section{MECHANISMS OF ASTROCYTE-MEDIATED NEUROVASCULAR COUPLING}

\section{Arachidonic Acid-Mediated Neurovascular Coupling}

Work over the past decade has shown that neurovascular coupling is mediated, to a significant degree, by a $\mathrm{Ca}^{2+}$-dependent astrocytic mechanism. The link between astrocyte $\mathrm{Ca}^{2+}$ and vascular changes was best shown by uncaging of $\mathrm{Ca}^{2+}$ in astrocytes in brain slices, retinal explants, and in vivo. These experiments showed unequivocally that $\mathrm{Ca}^{2+}$ transients in astrocytes can induce dilations and constrictions in adjacent arterioles. Mulligan and MacVicar (2004) showed that arterioles display constrictions as opposed to the dilations, reported by Zonta et al. (2003), when $\mathrm{Ca}^{2+}$ transients were evoked with two-photon $\mathrm{Ca}^{2+}$ uncaging in endfeet adjacent to arterioles. The arteriole responses were blocked by inhibiting phospholipase A2, the enzyme that liberates arachidonic acid (AA) from membrane lipids, and by inhibiting the conversion of AA to the vasoconstrictive lipid, 20-hydroxyeicosatetraenoic acid (20-HETE). In $\mathrm{Ca}^{2+}$ uncaging experiments in vivo, Takano et al. (2006) showed that arteriole dilations in the cortex were triggered by astrocyte $\mathrm{Ca}^{2+}$ transients via a mechanism sensitive to the inhibition of cylclooxygenase-1 (COX-1), one of the enzymes that synthesizes PGE2 from AA. Ta- 
kano et al. also showed that COX-1 was expressed in the endfeet of cortical astrocytes, supporting the role for PGE2 synthesis by astrocytes. These results suggested that PGE2 is released from astrocytes to cause arteriole dilations similar to the mechanism proposed by Zonta et al. (2003) (Fig. 3). The first hints of the complexity of astrocyte vascular coupling came from work in the retina explant by Metea and Newman (2006). They showed that, in the same preparation, $\mathrm{Ca}^{2+}$ uncaging in astrocytes and Müller cells (the principal retinal glial cells) could trigger both arteriole constrictions via 20-HETE synthesis and dilations via the formation of other vasoactive lipids and epoxyeicosa-
Astrocyte Regulation of Blood Flow in the Brain

trienoic acids (EETs), that are also synthesized from AA. Subsequent work by Mishra et al. (2011) showed that astrocyte-evoked vasodilation in the retina is mediated by synthesis of both EETs and PGE2.

Part of the explanation for the divergent observations that both dilations and constrictions could be triggered by astrocyte $\mathrm{Ca}^{2+}$ signaling came from the work of Gordon et al. (2008). In this study of brain slices, the investigators reported that the polarity of the vascular response to astrocyte $\mathrm{Ca}^{2+}$ transients was dependent on the level of $\mathrm{pO}_{2}$ in the superfusion solution. Arteriole constrictions that were evoked by $\mathrm{Ca}^{2+}$ uncaging in astrocytes in

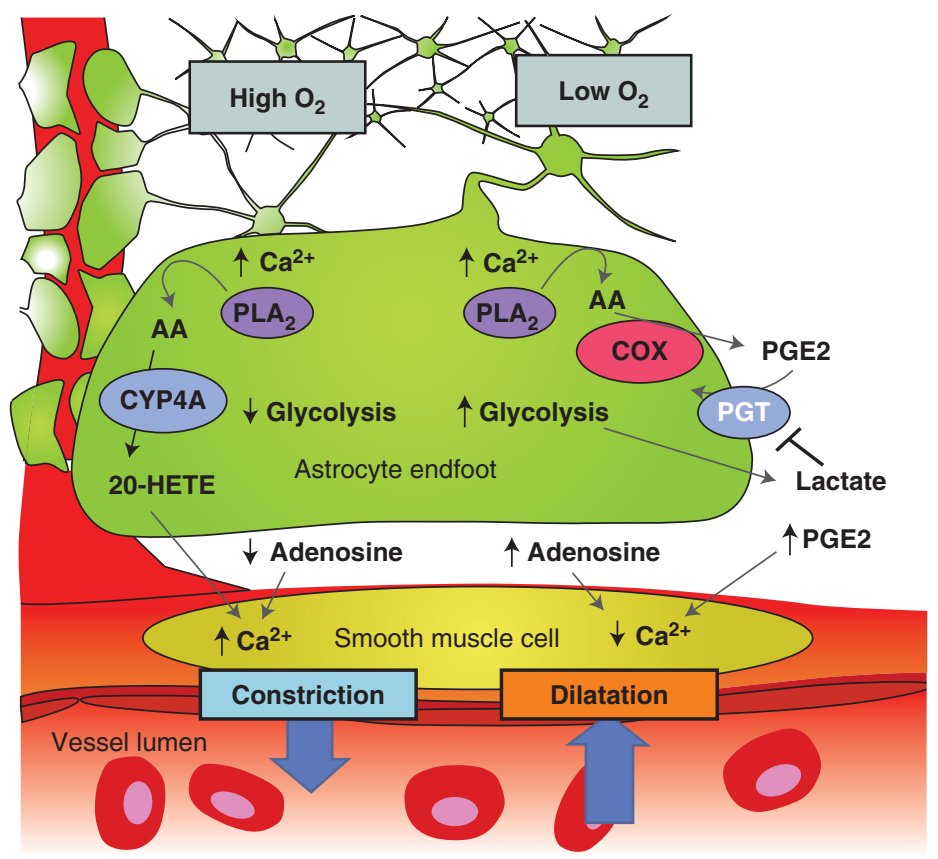

Figure 3. Summary of the modulation of arachidonic acid metabolite-mediated neurovascular coupling by tissue $\mathrm{pO}_{2}$ and lactate. Intracellular $\mathrm{Ca}^{2+}$ transients activate $\mathrm{PLA}_{2}$ to liberate arachidonic acid (AA) from plasma membrane lipids. In high $\mathrm{pO}_{2}, \mathrm{AA}$ is converted to 20-HETE, which increases intracellular $\mathrm{Ca}^{2+}$ in smooth muscle cells, causing vasoconstriction (left side). Extracellular adenosine that can inhibit $\mathrm{Ca}^{2+}$ entry into smooth muscle cells is also lower in high tissue $\mathrm{pO}_{2}$, further promoting vasoconstriction. In lower $\mathrm{pO}_{2}$ (right side), the vasodilation pathway dominates and AA is converted to PGE2 by COX-1 and is released by diffusion. Extracellular PGE2 is cleared from the extracellular space by the prostaglandin transporter (PGT), which is expressed in astrocytes and neurons. When $\mathrm{pO}_{2}$ decreases, glycolysis is enhanced and extracellular levels of lactate increase. Extracellular lactate attenuates PGE2 uptake by PGT leading to higher extracellular PGE2 and enhanced relaxation of smooth muscle tone and vasodilation. In addition, higher levels of extracellular adenosine reduces smooth muscle cell constriction via $\mathrm{A}_{2 \mathrm{~A}}$ activation. (From Gordon et al. 2011; reprinted, with permission, from the authors.) 
high $\mathrm{O}_{2}(95 \%)$ solutions were reversed to arteriole dilations in more physiological $(20 \%)$ solutions. Oxygen modulation of neurovascular coupling occurred because low $\mathrm{pO}_{2}$ increased extracellular lactate concentrations, which, in turn, reduced the uptake and clearance of PGE2 by the prostaglandin transporter. In high $\mathrm{pO}_{2}$, the conversion of AA to 20-HETE predominates, leading to constriction, whereas, in low $\mathrm{pO}_{2}$, the PGE2 dilation pathway is dominant (Fig. 3). In addition, the increased adenosine tone in low $\mathrm{pO}_{2}$ solutions reduced the vasoconstriction. A similar switch from dilation to constriction was observed in the retina explant when tissue $\mathrm{pO}_{2}$ was altered from a low $\mathrm{O}_{2}$ level to a high level (Mishra et al. 2011). However, this $\mathrm{O}_{2}$-modulatory effect on retinal blood flow was not observed in vivo when animals were made hyperoxic. The results of these experiments indicated that the polarity of astrocyte modulation of CBF may reflect the metabolic state of the brain tissue and may be modified by the level of the extracellular lactate concentration. It is intriguing that a link between the magnitude of CBF changes and lactate levels has been observed in awake human subjects in an fMRI study (Mintun et al. 2004), in which an increased lactate/pyruvate ratio was observed to augment blood flow in the physiologically activated human brain. In addition, a nuclear magnetic resonance (NMR) spectroscopy study showed a remarkably strong correlation between functional hyperemia and brain lactate levels (Lin et al. 2010).

The dilation or constriction of arteriole diameter as a result of $\mathrm{Ca}^{2+}$ transients in astrocyte endfeet has been replicated in numerous laboratories over the past 10 years. It is clear that $\mathrm{Ca}^{2+}$-dependent activation of $\mathrm{PLA}_{2}$ in astrocytes is an important initial step in the formation of vasoactive lipids that are synthesized from $A A$ and can trigger either arteriole dilations or constrictions. The reliance on $\mathrm{PLA}_{2}$ as the critical first step in this pathway has been supported by studies in $\mathrm{PLA}_{2}$ knockout transgenic mice, in which the ability of astrocyte $\mathrm{Ca}^{2+}$ signals to modify CBF is lost when the $\mathrm{Ca}^{2+}$-dependent form, $\mathrm{CPLA}_{2}$, is not expressed ( $\mathrm{He}$ et al. 2012). However, controversies remain concern- ing when $\mathrm{Ca}^{2+}$ signals are generated in astrocytes by synaptic activity and whether these $\mathrm{Ca}^{2+}$ signals precede the functional hyperemia response in vivo. Among the points of contention are:

- Glutamate mGluR5 receptors can mediate astrocyte $\mathrm{Ca}^{2+}$ signaling in juvenile but not in adult mice (Sun et al. 2013) and rats (Duffy and MacVicar 1995). It is not clear which receptors generate astrocytic $\mathrm{Ca}^{2+}$ signals in adults.

- Several neurotransmitters, besides glutamate, evoke $\mathrm{Ca}^{2+}$ signaling in astrocytes (Schipke and Kettenmann 2004) and could also lead to the modulation of CBF. However, release of these neurotransmitters is not consistently associated with neuronal activity as is glutamatergic signaling.

- It is well established that neuronal activity results in $\mathrm{Ca}^{2+}$ signaling in astrocytes in vivo. What is not clear, however, is how consistent this astrocytic $\mathrm{Ca}^{2+}$ signaling is and whether it precedes changes in CBF. Some studies have shown rapid $\mathrm{Ca}^{2+}$ signaling in astrocytes that precedes arteriole dilation (Winship et al. 2007; Lind et al. 2013). Other studies show that $\mathrm{Ca}^{2+}$ signaling occurs in few astrocytes and develops slowly after vasodilation has begun (Nizar et al. 2013; Bonder and McCarthy 2014; Paukert et al. 2014). These divergent results leave open the question of whether rapid functional hyperemia responses are mediated by a $\mathrm{Ca}^{2+}$ dependent astrocyte mechanism.

\section{Potassium-Mediated Neurovascular Coupling}

Neurovascular coupling may also be mediated by the glial release of $\mathrm{K}^{+}$onto blood vessels. When the extracellular $\mathrm{K}^{+}$concentration $\left(\left[\mathrm{K}^{+}\right]_{\mathrm{o}}\right)$ is increased from a resting level of $\sim 5 \mathrm{~mm}$ to $\sim 15 \mathrm{~mm}$, blood vessels dilate. Potassium-induced vasodilation is mediated by an increase in the conductance of inwardly rectifying $\mathrm{K}^{+}$channels on vascular smooth muscle cells (Filosa et al. 2006; Haddy et al. 2006) and by activation of the $\mathrm{Na}^{+}-\mathrm{K}^{+}$ATPase on the smooth muscle cells (Bunger et al. 1976; Haddy 
1983), both of which result in hyperpolarization and relaxation of the muscle cells. However, larger $\mathrm{K}^{+}$increases, above $\sim 15 \mathrm{~mm}$, depolarize vascular smooth muscle cells, resulting in vasoconstriction (Girouard et al. 2010). However, $\left[\mathrm{K}^{+}\right]_{\mathrm{o}}$ in the brain normally reaches $\sim 12 \mathrm{~mm}$ only during intense seizure activity and has not been observed to exceed $15 \mathrm{~mm}$ except during pathological processes, such as spreading depression or stroke (Vyskocil et al. 1972; Somjen 2001).

Active neurons release $\mathrm{K}^{+}$into the extracellular space, resulting in an increase in $\left[\mathrm{K}^{+}\right]_{\mathrm{o}}$. Light stimulation produces slow, transient $\left[\mathrm{K}^{+}\right]_{\mathrm{o}}$ increases of $\sim 1 \mathrm{~mm}$ in the cat visual cortex (Singer and Lux 1975; Connors et al. 1979) and in the synaptic layers of the cat and frog retina (Dick et al. 1985; Karwoski et al. 1985). Higher $\left[\mathrm{K}^{+}\right]_{\mathrm{o}}$ elevations are evoked by direct electrical stimulation of afferent pathways and by induction of seizure activity in the brain (Heinemann and Lux 1977).

Paulson and Newman (1987) proposed that neurovascular coupling is mediated by a feedforward glial cell $\mathrm{K}^{+}$siphoning mechanism (Newman et al. 1984). According to this model, the diffusion of $\mathrm{K}^{+}$through the extracellular space from neurons to blood vessels is enhanced by a $\mathrm{K}^{+}$current flow through astrocytes. The $\left[\mathrm{K}^{+}\right]_{\mathrm{o}}$ increase as a result of neuronal activity generates an influx of $\mathrm{K}^{+}$into astrocytes and results in astrocyte depolarization. Depolarization, in turn, induces a $\mathrm{K}^{+}$efflux from cell endfeet, which have a high density of $\mathrm{K}^{+}$channels (Newman 1984, 1986). Because astrocyte endfeet terminate on blood vessels, the $\mathrm{K}^{+}$efflux occurs directly onto the vessels. Computer simulations of $\mathrm{K}^{+}$dynamics (Paulson and Newman 1987) show that glial $\mathrm{K}^{+}$siphoning results in a $\mathrm{K}^{+}$increase at the vessel that is larger and more rapid than would occur solely by $\mathrm{K}^{+}$diffusion through the extracellular space. Potassium siphoned from astrocytes onto blood vessels could mediate neurovascular coupling.

More recently, the glial $\mathrm{K}^{+}$siphoning hypothesis of neurovascular coupling was tested in the retina (Metea et al. 2007). The results do not support the hypothesis. Glial cells were depolarized by current injection through patch
Astrocyte Regulation of Blood Flow in the Brain

pipettes. This depolarization should evoke $\mathrm{K}^{+}$ efflux from the cell endfeet and result in vasodilation. Although vessels dilated in response to bath-applied increases in $\left[\mathrm{K}^{+}\right]_{\mathrm{o}}$, current injection did not induce vasodilation. In a second test of the $\mathrm{K}^{+}$siphoning hypothesis, light-evoked vasodilation was assessed in mice in which Kir4.1 $\mathrm{K}^{+}$channels were genetically knocked out. Kir4.1 is the principal $\mathrm{K}^{+}$channel in retinal glial cells (Kofuji et al. 2000) and $\mathrm{K}^{+}$siphoning fluxes should be nearly abolished in Kir4.1 knockout animals. However, light-evoked vasodilation was as large in the knockout animals as in wild-type controls. The experiments show that glial cell $\mathrm{K}^{+}$siphoning does not contribute significantly to neurovascular coupling in the retina.

Although neurovascular coupling may not be mediated by $\mathrm{K}^{+}$siphoning, it could be mediated by a related $\mathrm{K}^{+}$mechanism. Astrocytes express big potassium $(\mathrm{BK}) \mathrm{Ca}^{2+}$-activated $\mathrm{K}^{+}$ channels as well as Kir channels (Price et al. 2002). When neuronal activity evokes $\mathrm{Ca}^{2+}$ increases in astrocytes, $\mathrm{BK} \mathrm{K}^{+}$channels will open (Filosa et al. 2006). BK channels are also modulated by arachidonic acid metabolites and $\mathrm{Ca}^{2+}$-dependent increases in EETs will open the channels (Gebremedhin et al. 2003; Dunn and Nelson 2010). BK channel opening will result in an efflux of $\mathrm{K}^{+}$from glial cell endfeet onto blood vessels, which could lead to vessel dilation. Genetic and pharmacological block of BK channels results in a reduction of whisker stimulation-evoked blood flow increases in the cortex, supporting this $\mathrm{K}^{+}$-glial BK channel hypothesis of neurovascular coupling (Filosa et al. 2006; Girouard et al. 2010).

\section{REGULATION OF BLOOD FLOW BY CAPILLARIES}

Within the brain vascular network, regulation of blood flow occurs at the level of arterioles, with neuronal activity leading to arteriole dilation and increased blood flow. Recent work has shown, however, that capillaries can actively regulate blood flow as well. Sensory stimulation leads to active dilation of brain capillaries (Chaigneau et al. 2003; Lacar et al. 2012; Hall 
et al. 2014), which could play an important role in regulating blood flow as a significant fraction of total vascular resistance likely resides in these small vessels (Blinder et al. 2013; Hall et al. 2014). Active regulation of blood flow by capillaries has also been shown in the retina, where flickering light stimulation results in the selective dilation of specific capillaries (Kornfield and Newman 2014).

Active control of capillary diameter is mediated by pericytes and their processes, which surround capillaries. Pericytes, the only cells associated with these vessels that express contractile proteins (Nehls and Drenckhahn 1991; Hughes and Chan-Ling 2004; Hamilton et al. 2010), can actively dilate and constrict in response to vasoactive agents (Schonfelder et al. 1998; Peppiatt et al. 2006; Puro 2007; Hamilton et al. 2010). Hall et al. (2014) have shown that pericytes in the somatosensory cortex actively relax in response to whisker-pad stimulation. The resulting capillary dilation precedes the dilation of upstream arterioles, demonstrating that pericytes play an important role in controlling blood flow.

There are still many unanswered questions concerning how neurovascular signaling mechanisms control pericyte tone. It is possible that some of the same glial and neuronal signaling mechanisms that control the tone of smooth muscles cells surrounding arterioles also modify pericyte tone. For example, Hall et al. (2014) showed that glutamate-induced pericyte relaxation is mediated by activation of PGE2 receptors and by nitric oxide (NO) inhibition of the synthesis of the vasoconstrictor 20-HETE. These are two of the same astrocyte-mediated signaling mechanisms that control the contractile state of arteriole smooth muscle cells.

\section{ASTROCYTE REGULATION OF VASCULAR BASAL TONE}

The supply of oxygen and nutrients to the brain is controlled by the basal tone of blood vessels, as well as by changes in tone that occur during functional hyperemia. Basal vascular tone is controlled by a number of mechanisms. These include extrinsic innervation from the auto- nomic nervous system, intrinsic innervation from subcortical neurons and cortical interneurons, and the local release of vasoactive agents from vascular cells (Hamel 2006). A number of vasoactive agents modulate cerebrovascular tone, including noradrenaline, released by sympathetic terminals and by locus coeruleus neurons (Bekar et al. 2012); serotonin, released by raphe nucleus neurons (Cohen et al. 1996); and neuropeptides, released from local interneurons (Cauli et al. 2004).

Vasoconstricting agents released from astrocytes also contribute to the generation of vascular tone. As discussed above, $\mathrm{Ca}^{2+}$ signaling in astrocytes results in the production of the vasoconstrictor 20-HETE, as well as the vasodilators PGE2 and EETs. 20-HETE is a wellknown vasoconstrictor of arteries and arterioles (Imig et al. 1996) and is thought to act by inhibiting $\mathrm{Ca}^{2+}$-activated $\mathrm{K}^{+}$channels and by activating voltage-gated $\mathrm{Ca}^{2+}$ channels on vascular smooth muscle cells (Zou et al. 1996). Cat cerebral arterial smooth muscle cells express cytochrome P450 4A enzymes and produce the vasoconstrictor 20-HETE, which enhances Ltype $\mathrm{Ca}^{2+}$ currents (Gebremedhin et al. 1998). In addition, Cyp450 4A2, the enzyme that synthesizes 20-HETE in smooth muscle cells, is inhibited by NO, a potent vasodilator (Oyekan et al. 1999). These studies indicate that a balance between 20-HETE and NO levels is important under some circumstances for setting the basal tone of cerebral blood vessels (Gordon et al. 2007; Metea and Newman 2007). This conclusion is supported by observations, in brain slices and in vivo, that blocking $\mathrm{NO}$ release leads to a vasoconstriction that is 20-HETE synthesis dependent (Zonta et al. 2003; Mulligan and MacVicar 2004). The importance of this pathway in setting basal tone was shown in a recent study that described a very long-lasting $(2 \mathrm{~h})$ decrease in $\mathrm{CBF}$ following spreading depression that was caused by increased 20-HETE in the cerebral cortex (Fordsmann et al. 2013).

Astrocytes also generate vascular tone by the tonic release of ATP (Kur and Newman 2013). Hippocampal astrocytes tonically release ATP, resulting in extracellular ATP levels of $\sim 10 \mu \mathrm{M}$ (Pascual et al. 2005), whereas astro- 
cytes and Müller cells in the retina release ATP in response to cellular $\mathrm{Ca}^{2+}$ increases (Newman 2001). Released ATP tonically constricts arterioles by activating $\mathrm{P} 2 \mathrm{X} 1$ receptors on vascular smooth muscle cells. Vascular tone is lowered when extracellular ATP levels are reduced by enzyme degradation, when $\mathrm{P} 2 \mathrm{X} 1$ receptors are blocked with purinergic antagonists, and when glial cells are selectively poisoned with the toxin fluorocitrate (Kur and Newman 2013).

\section{ASTROCYTES AND FUNCTIONAL HYPEREMIA IN PATHOLOGY}

\section{Alzheimer's Disease}

Alzheimer's disease is characterized, classically, by extracellular accumulation of amyloid plaques and intracellular protein inclusions, now known as neurofibrillary tangles (Alzheimer 1907; Kosik et al. 1986; Goedert et al. 1988; Graeber and Mehraein 1999). In addition, there are recent observations of physiological and phenotypic changes in the cells surrounding plaques in mouse models of Alzheimer's disease. For example, spontaneous intercellular $\mathrm{Ca}^{2+}$ waves and higher resting $\mathrm{Ca}^{2+}$ levels in astrocytes have been observed (Kuchibhotla et al. 2009), in addition to abnormal synchronous neuronal hyperactivity and signs of profound microglia activation (Terry et al. 1991; Akiyama et al. 2000; Wyss-Coray 2006; Venneti et al. 2008). These changes in astrocyte $\mathrm{Ca}^{2+}$ signaling could generate inappropriate neurovascular changes as there are several vasoactive lipids, described in this review, that are generated in response to $\mathrm{Ca}^{2+}$ signals in astrocytes. These alterations in both neuronal and astrocyte $\mathrm{Ca}^{2+}$ signaling could synergistically lead to impaired vascular control and possibly lead to constrictions of arterioles and tissue hypoxia (Mulligan and MacVicar 2004; Gordon et al. 2008; Attwell et al. 2010). In addition, the overproduction of amyloid- $\beta$ has been linked to the disrupted vasoregulation that occurs as a result of increased free-radical production via NADPH oxidase (Iadecola 2004; Park et al. 2005) that could be enhanced during transient hypoxia (Zhang et al. 2014). Disruptions in sig- naling to the brain's vascular network by glial cells, as well as neurons, could be important in the development of Alzheimer's dementia in addition to vascular dementia itself (Iadecola 2013).

\section{Diabetic Retinopathy}

Functional hyperemia is also disrupted in diabetic retinopathy. In healthy subjects, flickering light can dilate retinal arterioles by $\sim 7 \%$ (Polak et al. 2002; Garhofer et al. 2004a). This functional hyperemia response is substantially reduced in patients with type 1 and type 2 diabetes, in which flicker-evoked arteriole dilation is decreased by $\sim 60 \%$ (Fig. 4) (Garhofer et al. 2004b; Nguyen et al. 2009; Pemp et al. 2009). This reduction in functional hyperemia is also seen in an animal model of type 1 diabetic retinopathy (Mishra and Newman 2010, 2012). Importantly, the reduction in functional hyperemia, in both patients and in the animal model, is observed before the appearance of overt clinical retinopathy, suggesting that the loss of neurovascular coupling may be a causal factor in the development of retinal pathology (Mandecka et al. 2007; Mishra and Newman 2010).

The loss of functional hyperemia in the diabetic retina is likely caused by the disruption of signaling from glial cells to blood vessels. Glial-evoked dilation of blood vessels in the retina is reduced by NO (Metea and Newman 2006), presumably by NO inhibition of EETs production. In early stages of diabetic retinopathy, there is an up-regulation of inducible nitric oxide synthase (iNOS) (Du et al. 2002; Mishra and Newman 2010), leading to increased NO levels in the retina (Kowluru et al. 2000) and to a reduction in glial-evoked vessel dilation (Mishra and Newman 2010). However, when NO production is inhibited by selective iNOS blockers in diabetic animals, both glial-evoked and flicker-evoked vessel dilation is restored to control levels (Fig. 4B,C) (Mishra and Newman 2010, 2012). iNOS inhibitors may similarly restore neurovascular coupling in diabetic patients, and represents a possible therapy for slowing the progression of diabetic retinopathy. 
B.A. MacVicar and E.A. Newman
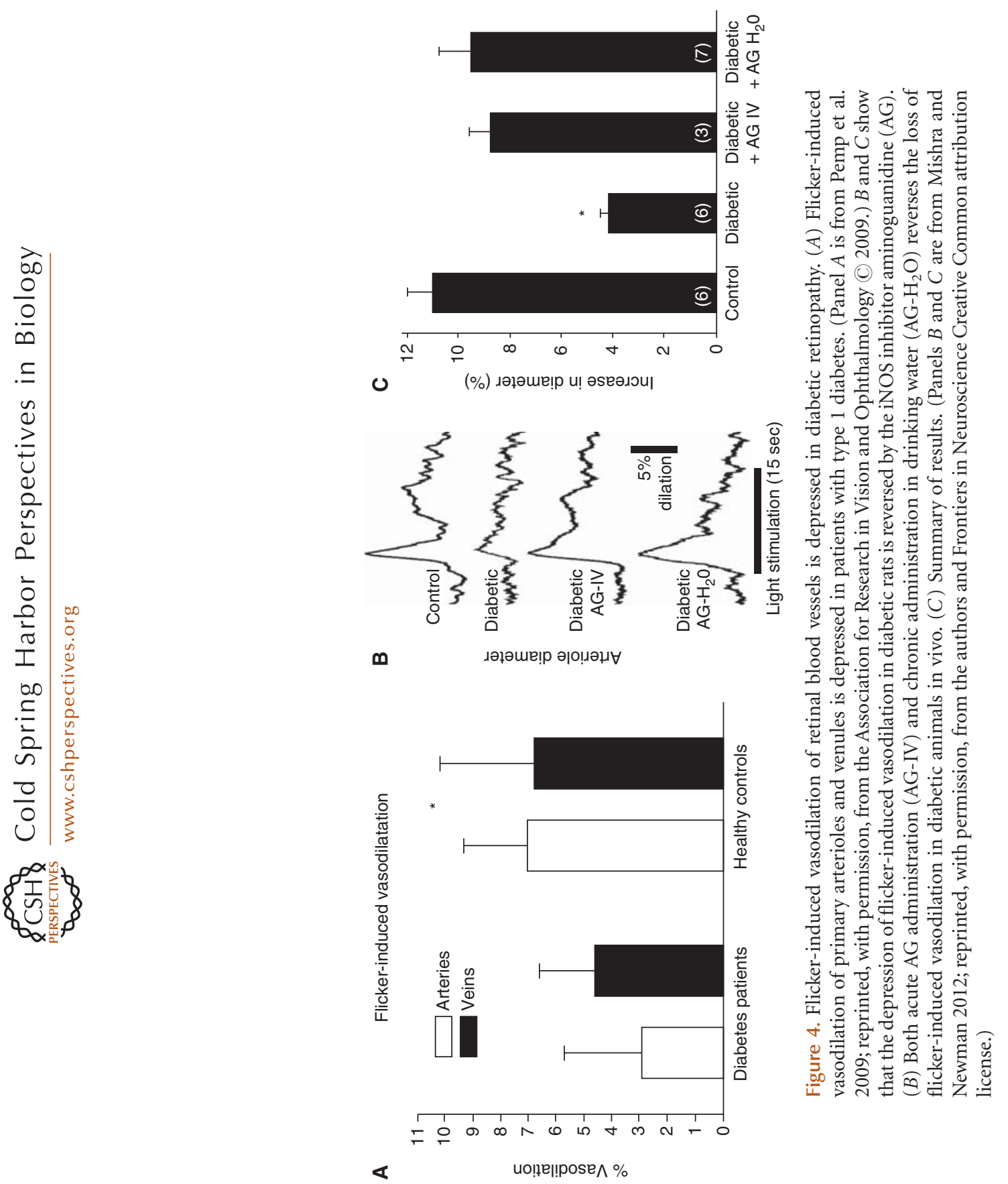


\section{CONCLUSION}

The regulation of CBF is essential for proper brain function. Numerous mechanisms, both neuronal and glial, contribute to blood flow regulation. Astrocytes contribute to the regulation of CBF in several ways. Calcium-dependent synthesis of metabolites of arachidonic acid by astrocytes modulates CBF. Synthesis of PGE2 and EETs dilate blood vessels, whereas 20-HETE constricts vessels. The release of $\mathrm{K}^{+}$ may also contribute to vasodilation. However, the precise role that astrocytes play in regulating blood flow remains an open question, as the neurotransmitters that evoke astrocytic $\mathrm{Ca}^{2+}$ signaling and the time course of the astrocytic $\mathrm{Ca}^{2+}$ signals remain in dispute. The metabolic state of the brain influences astrocytic control of $\mathrm{CBF}$, as $\mathrm{pO}_{2}$ levels determine whether vasodilation or constriction will dominate. Astrocytes also contribute to the generation of vascular tone. Tonic release of both 20-HETE and ATP from astrocytes constrict vascular smooth muscle cells, generating vessel tone. Under pathological conditions, including Alzheimer's disease and diabetic retinopathy, disruption of normal astrocyte physiology can compromise the regulation of blood flow.

\section{ACKNOWLEDGMENTS}

The authors' work is supported by Fondation Leducq of France (B.A.M. and E.A.N.), the Canadian Institutes of Health Research (CIHR) funding reference numbers 244825 and 245760 and TCE-117869 in the framework of the ERANET NEURON (B.A.M.), a Canada Research Chair (B.A.M.), and the National Institutes of Health of the United States (EY004077 and EY023216, E.A.N.).

\section{REFERENCES}

Akiyama H, Barger S, Barnum S, Bradt B, Bauer J, Cole GM, Cooper NR, Eikelenboom P, Emmerling M, Fiebich BL, et al. 2000. Inflammation and Alzheimer's disease. Neurobiol Aging 21: 383-421.

Alzheimer A. 1907. Über eine eigenartige Erkrankung der Hirnrinde [About a peculiar disease of the cerebral cortex]. Allg Z Psychiat 64: 146-148.
Attwell D, Buchan AM, Charpak S, Lauritzen M, MacVicar BA, Newman EA. 2010. Glial and neuronal control of brain blood flow. Nature 468: 232-243.

Bekar LK, Wei HS, Nedergaard M. 2012. The locus coeruleus-norepinephrine network optimizes coupling of cerebral blood volume with oxygen demand. J Cereb Blood Flow Metab 32: 2135-2145.

Blinder P, Tsai PS, Kaufhold JP, Knutsen PM, Suhl H, Kleinfeld D. 2013. The cortical angiome: An interconnected vascular network with noncolumnar patterns of blood flow. Nat Neurosci 16: 889-897.

Bonder DE, McCarthy KD. 2014. Astrocytic Gq-GPCRlinked IP3R-dependent $\mathrm{Ca}^{2+}$ signaling does not mediate neurovascular coupling in mouse visual cortex in vivo. $J$ Neurosci 34: 13139-13150.

Bunger R, Haddy FJ, Querengasser A, Gerlach E. 1976. Studies on potassium induced coronary dilation in the isolated guinea pig heart. Pflugers Arch 363: 27-31.

Cauli B, Tong XK, Rancillac A, Serluca N, Lambolez B, Rossier J, Hamel E. 2004. Cortical GABA interneurons in neurovascular coupling: Relays for subcortical vasoactive pathways. J Neurosci 24: 8940-8949.

Chaigneau E, Oheim M, Audinat E, Charpak S. 2003. Twophoton imaging of capillary blood flow in olfactory bulb glomeruli. Proc Natl Acad Sci 100: 13081-13086.

Cohen Z, Bonvento G, Lacombe P, Hamel E. 1996. Serotonin in the regulation of brain microcirculation. Prog Neurobiol 50: 335-362.

Connors B, Dray A, Fox P, Hilmy M, Somjen G. 1979. LSD's effect on neuron populations in visual cortex gauged by transient responses of extracellular potassium evoked by optical stimuli. Neurosci Lett 13: 147-150.

Devor A, Sakadzic S, Saisan PA, Yaseen MA, Roussakis E, Srinivasan VJ, Vinogradov SA, Rosen BR, Buxton RB, Dale AM, et al. 2011. "Overshoot" of $\mathrm{O}_{2}$ is required to maintain baseline tissue oxygenation at locations distal to blood vessels. J Neurosci 31: 13676-13681.

Dick E, Miller RF, Bloomfield S. 1985. Extracellular K ${ }^{+}$activity changes related to electroretinogram components: II. Rabbit (E-type) retinas. J Gen Physiol 85: 911-931.

Du Y, Smith MA, Miller CM, Kern TS. 2002. Diabetes-induced nitrative stress in the retina, and correction by aminoguanidine. J Neurochem 80: 771-779.

Duffy S, MacVicar BA. 1995. Adrenergic calcium signalling in astrocyte networks within the hippocampal slice. $J$ Neurosci 15: 5535-5550.

Dunn KM, Nelson MT. 2010. Potassium channels and neurovascular coupling. Circ J 74: 608-616.

Filosa JA, Bonev AD, Straub SV, Meredith AL, Wilkerson MK, Aldrich RW, Nelson MT. 2006. Local potassium signaling couples neuronal activity to vasodilation in the brain. Nat Neurosci 9: 1397-1403.

Fordsmann JC, Ko RWY, Choi HB, Thomsen K, Witgen BM, Mathiesen C, Lonstrup M, Piilgaard H, MacVicar BA, Lauritzen M. 2013. Increased 20-HETE synthesis explains reduced cerebral blood flow but not impaired neurovascular coupling after cortical spreading depression in rat cerebral cortex. J Neurosci 33: 2562-2570.

Garhofer G, Zawinka C, Resch H, Huemer KH, Dorner GT, Schmetterer L. 2004a. Diffuse luminance flicker increases 
blood flow in major retinal arteries and veins. Vision Res 44: 833-838.

Garhofer G, Zawinka C, Resch H, Kothy P, Schmetterer L, Dorner GT. 2004b. Reduced response of retinal vessel diameters to flicker stimulation in patients with diabetes. Br J Ophthalmol 88: 887-891.

Gebremedhin D, Lange AR, Narayanan J, Aebly MR, Jacobs ER, Harder DR. 1998. Cat cerebral arterial smooth muscle cells express cytochrome P450 4A2 enzyme and produce the vasoconstrictor 20-HETE which enhances Ltype $\mathrm{Ca}^{2+}$ current. J Physiol 507: 771-781.

Gebremedhin D, Yamaura K, Zhang C, Bylund J, Koehler RC, Harder DR. 2003. Metabotropic glutamate receptor activation enhances the activites of two types of $\mathrm{Ca}^{2+}$ activated $\mathrm{K}^{+}$channels in rat hippocampal astrocytes. $J$ Neurosci 23: 1678-1687.

Girouard H, Bonev AD, Hannah RM, Meredith A, Aldrich RW, Nelson MT. 2010. Astrocytic endfoot $\mathrm{Ca}^{2+}$ and BK channels determine both arteriolar dilation and constriction. Proc Natl Acad Sci 107: 3811-3816.

Goedert M, Wischik CM, Crowther RA, Walker JE, Klug A. 1988. Cloning and sequencing of the cDNA encoding a core protein of the paired helical filament of Alzheimer disease: Identification as the microtubule-associated protein tau. Proc Natl Acad Sci 85: 4051-4055.

Golgi C. 1894. Untersuchungen über den feineren bau des zentralen und peripherischen nervensystems [Studies on the finer construction of the central and peripheral nervous system]. Gustav Fischer, Jena, Germany.

Gordon GRJ, Mulligan SJ, MacVicar BA. 2007. Astrocyte control of the cerebrovasculature. Glia 55: 1214-1221.

Gordon GRJ, Choi HB, Rungta RL, Ellis-Davies GCR, MacVicar BA. 2008. Brain metabolism dictates the polarity of astrocyte control over arterioles. Nature 456: 745-749.

Gordon GRJ, Howarth C, MacVicar BA. 2011. Bidirectional control of arteriole diameter by astrocytes. Exp Physiol 96: 393-399.

Graeber MB, Mehraein P. 1999. Reanalysis of the first case of Alzheimer's disease. Eur Arch Psychiatry Clin Neurosci 249: $10-13$.

Haddy FJ. 1983. Potassium effects on contraction in arterial smooth muscle mediated by $\mathrm{Na}^{+}, \mathrm{K}^{+}$-ATPase. FASEB $J$ 42: $239-243$.

Haddy FJ, Vanhoutte PM, Feletou M. 2006. Role of potassium in regulating blood flow and blood pressure. Am J Physiol Regul Integr Comp Physiol 290: R546-R552.

Hall CN, Reynell C, Gesslein B, Hamilton NB, Mishra A, Sutherland BA, O'Farrell FM, Buchan AM, Lauritzen M, Attwell D. 2014. Capillary pericytes regulate cerebral blood flow in health and disease. Nature 508: 55-60.

Hamel E. 2006. Perivascular nerves and the regulation of cerebrovascular tone. J Appl Physiol 100: 1059-1064.

Hamilton NB, Attwell D, Hall CN. 2010. Pericyte-mediated regulation of capillary diameter: A component of neurovascular coupling in health and disease. Front Neuroenerg 2: 5 .

He L, Linden DJ, Sapirstein A. 2012. Astrocyte inositol triphosphate receptor type 2 and cytosolic phospholipase $\mathrm{A}_{2} \alpha$ regulate arteriole responses in mouse neocortical brain slices. PLoS ONE 7: e42194.
Heinemann U, Lux HD. 1977. Ceiling of stimulus induced rises in extracellular potassium concentration in the cerebral cortex of cat. Brain Res 120: 231-249.

Howarth C, Gleeson P, Attwell D. 2012. Updated energy budgets for neural computation in the neocortex and cerebellum. J Cereb Blood Flow Metab 32: 1222-1232.

Hughes S, Chan-Ling T. 2004. Characterization of smooth muscle cell and pericyte differentiation in the rat retina in vivo. Invest Ophthalmol Vis Sci 45: 2795-2806.

Iadecola C. 2004. Neurovascular regulation in the normal brain and in Alzheimer's disease. Nat Rev Neurosci 5: $347-360$.

Iadecola C. 2013. The pathobiology of vascular dementia. Neuron 80: 844-866.

Imig JD, Zou AP, Stec DE, Harder DR, Falck JR, Roman RJ. 1996. Formation and actions of 20-hydroxyeicosatetraenoic acid in rat renal arterioles. Am J Physiol 270: R217R227.

Karwoski CJ, Newman EA, Shimazaki H, Proenza LM. 1985. Light-evoked increases in extracellular $\mathrm{K}^{+}$in the plexiform layers of amphibian retinas. J Gen Physiol 86: 189213.

Kofuji P, Ceelen PW, Zahs KR, Surbeck LW, Lester HA, Newman EA. 2000. Genetic inactivation of an inwardly rectifying potassium channel (Kir4.1 subunit) in mice: Phenotypic impact in retina. J Neurosci 20: 5733-5740.

Kornfield TE, Newman EA. 2014. Regulation of blood flow in the retinal trilaminar vascular network. J Neurosci 34: 11504-11513.

Kosik KS, Joachim CL, Selkoe DJ. 1986. Microtubule-associated protein tau $(\tau)$ is a major antigenic component of paired helical filaments in Alzheimer disease. Proc Natl Acad Sci 83: 4044-4048.

Kowluru RA, Engerman RL, Kern TS. 2000. Abnormalities of retinal metabolism in diabetes or experimental galactosemia VIII: Prevention by aminoguanidine. Curr Eye Res 21: 814-819.

Kuchibhotla KV, Lattarulo CR, Hyman BT, Bacskai BJ. 2009. Synchronous hyperactivity and intercellular calcium waves in astrocytes in Alzheimer mice. Science 323: 1211-1215.

Kur J, Newman EA. 2013. Purinergic control of vascular tone in the retina. J Physiol 592: 491-504.

Lacar B, Herman P, Hartman NW, Hyder F, Bordey A. 2012. $S$ phase entry of neural progenitor cells correlates with increased blood flow in the young subventricular zone. PLoS ONE 7: e31960.

Lin AL, Fox PT, Hardies J, Duong TQ, Gao JH. 2010. Nonlinear coupling between cerebral blood flow, oxygen consumption, and ATP production in human visual cortex. Proc Natl Acad Sci 107: 8446-8451.

Lind BL, Brazhe AR, Jessen SB, Tan FCC, Lauritzen MJ. 2013. Rapid stimulus-evoked astrocyte $\mathrm{Ca}^{2+}$ elevations and hemodynamic responses in mouse somatosensory cortex in vivo. Proc Natl Acad Sci 110: E4678-E4687.

Magistretti PJ, Pellerin L, Martin JL. 2000. Brain energy metabolism: An integrated cellular perspective. In Psychopharmacology -4 th generation of progress (ed. Bloom FE, Kupfer DJ), Raven, New York.

Mandecka A, Dawczynski J, Blum M, Muller N, Kloos C, Wolf G, Vilser W, Hoyer H, Muller UA. 2007. Influence of 
flickering light on the retinal vessels in diabetic patients. Diabetes Care 30: 3048-3052.

Metea MR, Newman EA. 2006. Glial cells dilate and constrict blood vessels: A mechanism of neurovascular coupling. J Neurosci 26: 2862-2870.

Metea MR, Newman EA. 2007. Signaling within the neurovascular unit in the retina. Exp Physiol 924: 635-640.

Metea MR, Kofuji P, Newman EA. 2007. Neurovascular coupling is not mediated by potassium siphoning from glial cells. J Neurosci 27: 2468-2471.

Mintun MA, Vlassenko AG, Rundle MM, Raichle ME. 2004 Increased lactate/pyruvate ratio augments blood flow in physiologically activated human brain. Proc Natl Acad Sci 101: 659-664.

Mishra A, Newman EA. 2010. Inhibition of inducible nitric oxide synthase reverses the loss of functional hyperemia in diabetic retinopathy. Glia 58: 1996-2004.

Mishra A, Newman EA. 2012. Aminoguanidine reverses the loss of functional hyperemia in a rat model of diabetic retinopathy. Front Neuroenerg 3: 10.

Mishra A, Hamid A, Newman EA. 2011. Oxygen modulation of neurovascular coupling in the retina. Proc Natl Acad Sci 108: $17827-17831$.

Mosso A. 1880. Sulla circolazione del sangue nel cervello dell'uomo [On the circulation of blood in the human brain]. $R$ Accad Lincei 5: 237-358.

Mulligan SJ, MacVicar BA. 2004. Calcium transients in astrocyte endfeet cause cerebrovascular constrictions. $\mathrm{Na}$ ture 431: 195-199.

Nehls V, Drenckhahn D. 1991. Heterogeneity of microvascular pericytes for smooth muscle type $\alpha$-actin. J Cell Biol 113: $147-154$.

Newman EA. 1984. Regional specialization of retinal glial cell membrane. Nature 309: 155-157.

Newman EA. 1986. High potassium conductance in astrocyte endfeet. Science 233: 453-454.

Newman EA. 2001. Propagation of intercellular calcium waves in retinal astrocytes and Müller cells. J Neurosci 21: 2215-2223.

Newman EA, Frambach DA, Odette LL. 1984. Control of extracellular potassium levels by retinal glial cell $\mathrm{K}^{+}$siphoning. Science 225: 1174-1175.

Nguyen TT, Kawasaki R, Wang JJ, Kreis AJ, Shaw J, Vilser W, Wong TY. 2009. Flicker light-induced retinal vasodilation in diabetes and diabetic retinopathy. Diabetes Care 32: 2075-2080.

Nizar K, Uhlirova H, Tian P, Saisan PA, Cheng Q, Reznichenko L, Weldy KL, Steed TC, Sridhar VB, MacDonald CL, et al. 2013. In vivo stimulus-induced vasodilation occurs without $\mathrm{IP}_{3}$ receptor activation and may precede astrocytic calcium increase. J Neurosci 33: 8411-8422.

Offenhauser N, Thomsen K, Caesar K, Lauritzen M. 2005. Activity-induced tissue oxygenation changes in rat cerebellar cortex: Interplay of postsynaptic activation and blood flow. J Physiol 565: 279-294.

Oyekan AO, Youseff T, Fulton D, Quilley J, McGiff JC 1999. Renal cytochrome P450 $\omega$-hydroxylase and epoxygenase activity are differentially modified by nitric oxide and sodium chloride. J Clin Invest 104: 1131-1137.
Astrocyte Regulation of Blood Flow in the Brain

Park L, Anrather J, Zhou P, Frys K, Pitstick R, Younkin S, Carlson GA, Iadecola C. 2005. NADPH-oxidase-derived reactive oxygen species mediate the cerebrovascular dysfunction induced by the amyloid $\beta$ peptide. J Neurosci 25 : 1769-1777.

Pascual O, Casper KB, Kubera C, Zhang J, Revilla-Sanchez R, Sul JY, Takano H, Moss SJ, McCarthy K, Haydon PG. 2005. Astrocytic purinergic signaling coordinates synaptic networks. Science 310: 113-116.

Paukert M, Agarwal A, Cha J, Doze VA, Kang JU, Bergles DE. 2014. Norepinephrine controls astroglial responsiveness to local circuit activity. Neuron 82: 1263-1270.

Paulson OB, Newman EA. 1987. Does the release of potassium from astrocyte endfeet regulate cerebral blood flow? Science 237: 896-898.

Pemp B, Garhofer G, Weigert G, Karl K, Resch H, Wolzt M, Schmetterer L. 2009. Reduced retinal vessel response to flicker stimulation but not to exogenous nitric oxide in type 1 diabetes. Invest Ophthalmol Vis Sci 50: 40294032.

Peppiatt CM, Howarth C, Mobbs P, Attwell D. 2006. Bidirectional control of CNS capillary diameter by pericytes. Nature 443: 700-704.

Polak K, Schmetterer L, Riva CE. 2002. Influence of flicker frequency on flicker-induced changes of retinal vessel diameter. Invest Ophthalmol Vis Sci 43: 2721-2726.

Price DL, Ludwig JW, Mi H, Schwarz TL, Ellisman MH. 2002. Distribution of $r S l o \mathrm{Ca}^{2+}$-activated $\mathrm{K}^{+}$channels in rat astrocyte perivascular endfeet. Brain Res 956: 183-193.

Puro DG. 2007. Physiology and pathobiology of the pericyte-containing retinal microvasculature: New developments. Microcirculation 14: 1-10.

Ramón y Cajal S. 1895. Algunas conjeturas sobre el mecanismo anatómico de la ideación, asociación y atención [Some conjectures on the anatomical mechanism of ideation, association and attention]. Rev Med Cirugía Prácticas 19: 497-508.

Ramón y Cajal S. 1995. Histology of the nervous system of man and vertebrates (trans. Swanson N, Swanson LW). Oxford University Press, New York.

Roy CS, Sherrington CS. 1890. On the regulation of the blood-supply of the brain. J Physiol 11: 85-108.

Schipke CG, Kettenmann H. 2004. Astrocyte responses to neuronal activity. Glia 47: 226-232.

Schonfelder U, Hofer A, Paul M, Funk RH. 1998. In situ observation of living pericytes in rat retinal capillaries. Microvascu Res 56: 22-29.

Singer W, Lux HD. 1975. Extracellular potassium gradients and visual receptive fields in the cat striate cortex. Brain Res 96: 378-383.

Somjen GG. 2001. Mechanisms of spreading depression and hypoxic spreading depression-like depolarization. Physiol Rev 81: 1065-1096.

Sun W, McConnell E, Pare JF, Xu Q, Chen M, Peng W, Lovatt D, Han X, Smith Y, Nedergaard M. 2013. Glutamatedependent neuroglial calcium signaling differs between young and adult brain. Science 339: 197-200.

Takano T, Tian GF, Peng W, Lou N, Libionka W, Han X, Nedergaard M. 2006. Astrocyte-mediated control of cerebral blood flow. Nat Neurosci 9: 260-267. 


\section{B.A. MacVicar and E.A. Newman}

Terry RD, Masliah E, Salmon DP, Butters N, DeTeresa R, Hill R, Hansen LA, Katzman R. 1991. Physical basis of cognitive alterations in Alzheimer's disease: Synapse loss is the major correlate of cognitive impairment. Ann Neurol 30: $572-580$.

Venneti S, Wang G, Nguyen J, Wiley CA. 2008. The positron emission tomography ligand DAA1106 binds with high affinity to activated microglia in human neurological disorders. J Neuropathol Exp Neurol 67: 10011010.

Virchow RL. 1858. Cellular pathology as based upon physiological and pathological histology. John Churchill, London.

Vyskocil F, Kritz N, Bures J. 1972. Potassium-selective microelectrodes used for measuring the extracellular brain potassium during spreading depression and anoxic depolarization in rats. Brain Res 39: 255-259.

Winship IR, Plaa N, Murphy TH. 2007. Rapid astrocyte calcium signals correlate with neuronal activity and onset of the hemodynamic response in vivo. $J$ Neurosci 27: 6268-6272.

Wyss-Coray T. 2006. Inflammation in Alzheimer disease: Driving force, bystander or beneficial response? Nat Med 12: 1005-1015.

Zhang J, Malik A, Choi HB, Ko RWY, Dissing-Olesen L, MacVicar BA. 2014. Microglial CR3 activation triggers long-term synaptic depression in the hippocampus via NADPH oxidase. Neuron 82: 195-207.

Zonta M, Angulo MC, Gobbo S, Rosengarten B, Hossmann KA, Pozzan T, Carmignoto G. 2003. Neuron-to-astrocyte signaling is central to the dynamic control of brain microcirculation. Nat Neurosci 6: 43-50.

Zou AP, Fleming JT, Falck JR, Jacobs ER, Gebremedhin D, Harder DR, Roman RJ. 1996. 20-HETE is an endogenous inhibitor of the large-conductance $\mathrm{Ca}^{2+}$-activated $\mathrm{K}^{+}$channel in renal arterioles. Am J Physiol 270: R228R237. 


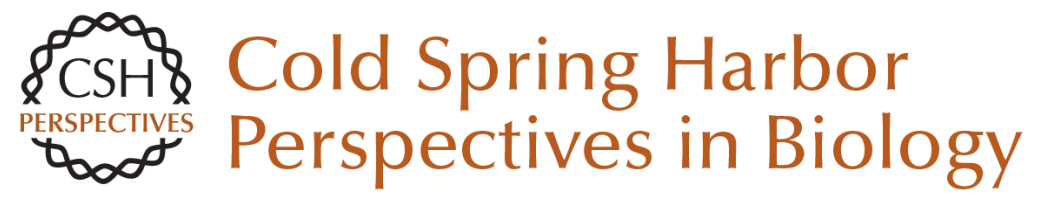

\section{Astrocyte Regulation of Blood Flow in the Brain}

Brian A. MacVicar and Eric A. Newman

Cold Spring Harb Perspect Biol 2015; doi: 10.1101/cshperspect.a020388 originally published online March 27, 2015

\section{Subject Collection Glia}

The Nodes of Ranvier: Molecular Assembly and Maintenance

Matthew N. Rasband and Elior Peles

Microglia in Health and Disease

Richard M. Ransohoff and Joseph El Khoury

The Astrocyte: Powerhouse and Recycling Center Bruno Weber and L. Felipe Barros

Microglia Function in Central Nervous System

Development and Plasticity

Dorothy P. Schafer and Beth Stevens

Transcriptional and Epigenetic Regulation of Oligodendrocyte Development and Myelination in the Central Nervous System

Ben Emery and Q. Richard Lu

Origin of Microglia: Current Concepts and Past

Controversies

Florent Ginhoux and Marco Prinz

Glia Disease and Repair--Remyelination

Robin J.M. Franklin and Steven A. Goldman

Astrocytes in Neurodegenerative Disease

Hemali Phatnani and Tom Maniatis
Oligodendrocyte Development and Plasticity Dwight E. Bergles and William D. Richardson

Oligodendrocytes: Myelination and Axonal

Support Mikael Simons and Klaus-Armin Nave

Drosophila Central Nervous System Glia Marc R. Freeman

Perisynaptic Schwann Cells at the Neuromuscular

Synapse: Adaptable, Multitasking Glial Cells Chien-Ping Ko and Richard Robitaille

Astrocytes Control Synapse Formation, Function, and Elimination Won-Suk Chung, Nicola J. Allen and Cagla Eroglu

Schwann Cell Myelination James L. Salzer

Schwann Cells: Development and Role in Nerve Repair

Kristján R. Jessen, Rhona Mirsky and Alison C. Lloyd

Perineurial Glia

Sarah Kucenas

For additional articles in this collection, see http://cshperspectives.cshlp.org/cgi/collection/

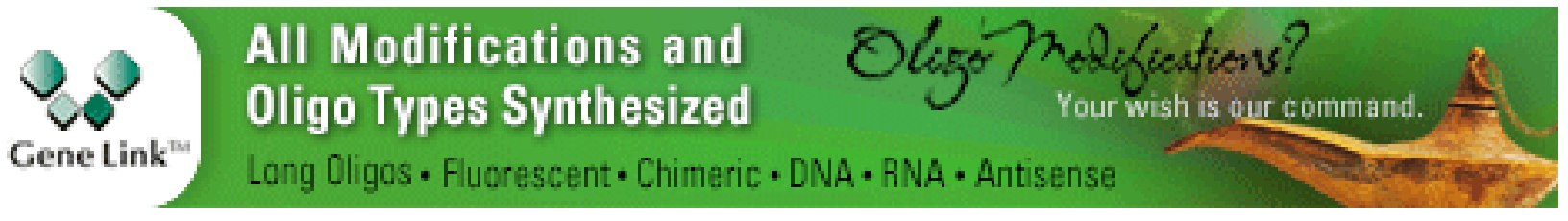

Copyright @ 2015 Cold Spring Harbor Laboratory Press; all rights reserved 